\title{
PENGARUH PEMAHAMAN, SANKSI PERPAJAKAN, TINGKAT KEPERCAYAAN PADA PEMERINTAH DAN HUKUM, SERTA NASIONALISME TERHADAP KEPATUHAN WAJIB PAJAK DALAM MEMBAYAR PBB-P2 (Studi Pada Wajib Pajak PBB-P2 di Kota Banjar)
}

\author{
Apriani Purnamasari \\ Umi Pratiwi \\ Sukirman \\ Universitas Jenderal Soedirman
}

\begin{abstract}
The main purpose of this research is to examine the effect of perceived tax understanding, tax penalties, trust in government and law, and nationalism towards taxpayer compliance in paying property tax. Using Slovin formula, 100 respondents were selected as representative sample from the tax payers in Banjar, Indonesia. Data were collected using closed questionnaire and analyzed by multiple linear regression. The results showed that the understanding of tax regulation, tax penalties, and nationalism had significantly positive effect. However, trust in goverment and the law did not significantly affect taxpayer compliance in paying property tax.
\end{abstract}

Keyword: Understanding of Tax Regulation, Tax Penalties, Trust in Goverment and Law, Nationalism

\section{PENDAHULUAN}

Pajak adalah iuran rakyat kepada kas negara berdasarkan undang-undang (yang dapat dipaksakan) dengan tidak mendapat jasa timbal (kontraprestasi) yang langsung dapat ditunjukkan dan yang dipergunakan untuk membayar pengeluaran umum (Mardiasmo, 2011). Sekarang ini pendapatan terbesar negara berasal dari sektor perpajakan. Menurut data yang diperoleh dari website Kementerian Keuangan (2015), realisasi penerimaan pajak tahun 2014 sebesar Rp. 1.143,3 triliun atau $74,37 \%$ dari total pendapatan negara. Sampai 31 Agustus 2015, realisasi penerimaan pajak telah mencapai $\mathrm{Rp}$.
598,270 triliun. Sedangkan sesuai APBN-P 2015 target penerimaan pajak sebesar Rp. 1.294,258 triliun, maka realisasi penerimaan pajak sudah mencapai $46,22 \%$ (Direktorat Jenderal Pajak, 2015).

$$
\text { Pemerintah melakukan berbagai }
$$
upaya untuk meningkatkan penerimaan pajak. Hal ini tidak hanya dilakukan pemerintah pusat tetapi dilakukan pula oleh pemerintah daerah. Penggelompokan pajak menurut lembaga pemungutnya dibedakan menjadi pajak pusat dan pajak daerah (Mardiasmo, 2011). Sekarang ini pungutan daerah yang berupa pajak dan retribusi diatur dengan Undang-Undang No. 28 Tahun 2009 tentang Pajak Daerah dan 
Retribusi Daerah. Pemerintah daerah diberi kewenangan yang lebih dalam mengatur kebijakan perpajakan karena hasil penerimaan pajak dan retribusi diakui belum memadai dan memiliki peranan yang relatif kecil terhadap APBD sehingga dengan adanya kebijakan tersebut maka pemerintah daerah dapat lebih optimal dalam meningkatkan pendapatan asli daerahnya.

Jenis pajak daerah yang baru salah satunya yaitu mengenai Pajak Bumi dan Bangunan Sektor Perdesaan dan Perkotaan (PBB-P2). Pengelolaan pajak bumi dan bangunan sektor perdesaan dan perkotaan sebelumnya dikelola oleh pemerintah pusat namun sekarang diserahkan kepada pemerintah daerah. Berbagai upaya telah dilakukan pemerintah daerah untuk memaksimalkan penerimaan pajak bumi dan bangunan sektor perdesaan dan perkotaan, namun hal tersebut tidak akan berarti apapun tanpa dukungan dari masyarakat. Banyak faktor yang dapat mempengaruhi kepatuhan wajib pajak dalam membayar pajak bumi dan bangunan, diantaranya faktor pemahaman wajib pajak mengenai peraturan perpajakan, sanksi perpajakan, tingkat kepercayaan pada pemerintah dan hukum, serta nasionalisme (Alm, Vazquez, and Torgler 2005; Jatmiko 2006; Fauziyah 2008; Handayani, Faturokhman dan Pratiwi 2012).
Penelitian ini merupakan replikasi dari penelitian Alm, Vazquez, and Torgler (2005), Russian Attitudes Toward Paying Taxes- Before, During, and After the Transition. Perbedaan dalam penelitian ini, diantaranya: adanya penambahan variabel independen, yaitu variabel pemahaman wajib pajak mengenai peraturan perpajakan dan variabel sanksi perpajakan. Perbedaan selanjutnya mengenai lokasi penelitian, dimana penelitian Alm, Vazquez, and Torgler (2005) dilakukan di Rusia sedangkan penelitian kali ini akan dilakukan di Indonesia yang membahas mengenai kepatuhan wajib pajak dalam membayar PBB.

Penelitian ini akan dilakukan pada wajib pajak PBB-P2 di Kota Banjar, Jawa Barat. Wacana penghapusan Pajak Bumi dan Bangunan (PBB) non komersial yang sebelumnya ramai diberitakan, membuat Kota Banjar menjadi resah karena hal tersebut berdampak nyata menurunkan tingkat kepatuhan wajib pajak menunaikan kewajiban membayar PBB. Pada bulan April 2015, dari sekitar 103.000 wajib pajak di Kota Banjar, yang sudah membayar PBB baru sekitar 19 persen. Dibandingkan waktu yang sama pada tahun 2014, ada penurunan sekitar 11 persen, pada saat itu pelunasan PBB mencapai 30 persen (Nurhandoko Wiyoso, 2015). Oleh karena itu peneliti ingin meneliti apakah pemahaman wajib pajak mengenai 
peraturan perpajakan; sanksi perpajakan; tingkat kepercayaan pada pemerintah dan hukum; serta nasionalisme mempengaruhi terhadap kepatuhan wajib pajak dalam membayar PBB-P2. Adapun tujuan penelitian ini, antara lain adalah untuk menguji secara empiris pengaruh pemahaman wajib pajak mengenai peraturan perpajakan, sanksi perpajakan, tingkat kepercayaan pada pemerintah, serta nasionalisme terhadap kepatuhan wajib pajak dalam membayar PBB-P2.

\section{LANDASAN TEORI DAN}

PENGEMBANGAN HIPOTESIS

\section{Teori Atribusi}

Teori atribusi menyatakan bahwa bila individu-individu mengamati perilaku seseorang, mereka mencoba untuk menentukan apakah itu ditimbulkan secara internal atau eksternal (Robbins, 2001). Dalam kepatuhan wajib pajak sangat berkaitan dengan sikap wajib pajak dalam membuat penilaian terhadap pajak itu sendiri. Persepsi seseorang untuk membuat penilaian mengenai orang lain sangat dipengaruhi oleh kondisi internal maupun eksternal orang tersebut. Teori atribusi sangat relevan untuk menerangkan maksud tersebut.

Teori Tindakan Beralasan (Theory of Reasoned Action)

Teori tindakan beralasan adalah suatu teori yang menjelaskan minat seseorang dalam melakukan suatu perilaku (Jogiyanto, 2007). Teori ini dikembangkan oleh Martin Fishbein dan Icek Ajzen (1980). Theory of Reasoned Action sangat relevan dengan penelitian ini, karena seseorang dalam menentukan perilaku patuh atau tidak patuh dalam memenuhi kewajiban perpajakannya dipengaruhi oleh rasionalitas dan juga pengaruh lingkungan yang berhubungan dengan pembentukan norma subjektif yang mempengaruhi keputusan perilaku wajib pajak (Imelda, 2014).

\section{Pengaruh Pemahaman Wajib Pajak Mengenai Peraturan Perpajakan Terhadap Kepatuhan Wajib Pajak Dalam Membayar PBB}

Pemahaman berasal dari kata "Paham" yang artinya mengerti benar; tahu benar akan tentang sesuatu hal. Pemahaman adalah proses, cara, perbuatan memahami atau memahamkan (Kamus Besar Bahasa Indonesia, 2015). Sedangkan menurut Soekidjo (2007) dalam Handayani, Faturokhman, dan Pratiwi (2012), memahami adalah suatu kemauan untuk menjelaskan secara benar tentang objek yang diketahui dan dapat menginterprestasikan materi tersebut secara benar. Berdasarkan teori atribusi, pemahaman wajib pajak mengenai peraturan perpajakan merupakan penyebab internal yang dapat mempengaruhi persepsi 
wajib pajak dalam membuat keputusan mengenai perilaku kepatuhan wajib pajak dalam melaksanakan kewajiban perpajakannya.

Perumusan hipotesis dalam penelitian ini lebih mengacu kepada penelitian Handayani, Faturokhman, dan Pratiwi (2012), Fauziyah (2008), dan Adiasa (2013) yang menyatakan bahwa pengaruh pemahaman wajib pajak mengenai peraturan perpajakan akan meningkatkan kepatuhan wajib pajak dalam membayar PBB. Argumentasi yang dipakai adalah wajib pajak yang memiliki pemahaman mengenai peraturan perpajakan akan lebih mengerti mengenai apa yang menjadi kewajibannya sebagai wajib pajak yang baik sehingga kewajibannya tersebut akan dipenuhi dan menyebabkan meningkatnya kepatuhan wajib pajak dalam membayar PBB. Berdasarkan penjelasan diatas dapat diambil hipotesis sebagai berikut:

$\mathrm{H}_{1}$ : Pemahaman wajib pajak mengenai peraturan perpajakan berpengaruh terhadap kepatuhan wajib pajak dalam membayar PBB.

Pengaruh Sanksi Perpajakan Terhadap Kepatuhan Wajib Pajak Dalam Membayar PBB

Sanksi adalah hukuman negatif kepada orang yang melanggar peraturan. Sanksi perpajakan yaitu persepsi masyarakat terhadap hukuman atas pelanggaran dalam memenuhi ketentuan dalam melaksanakan kewajiban perpajakan PBB (Jatmiko, 2006). Dengan kata lain sanksi perpajakan merupakan alat pencegah agar wajib pajak tidak melanggar norma perpajakan (Mardiasmo, 2011). Berdasarkan teori atribusi, sanksi perpajakan merupakan penyebab eksternal yang dapat mempengaruhi persepsi wajib pajak dalam membuat keputusan mengenai perilaku kepatuhan wajib pajak dalam melaksanakan kewajiban perpajakannya.

Perumusan hipotesis dalam penelitian ini lebih mengacu kepada penelitian Permatasari dan Yaniartha (2012), Rustiyaningsih (2011), Jatmiko (2006), Wulandari dan Suyanto (2014) yang menyimpulkan sanksi perpajakan berpengaruh terhadap kepatuhan wajib pajak. Argumentasi yang dipakai adalah semakin berat sanksi perpajakan yang dikenakan bagi wajib pajak yang melanggar peraturan maka wajib pajak semakin takut untuk melanggar sehingga akan meningkatkan kepatuhan wajib pajak dalam membayar PBB. Berdasarkan penjelasan diatas dapat diambil hipotesis sebagai berikut:

$\mathrm{H}_{2}$ : Sanksi perpajakan berpengaruh terhadap kepatuhan wajib pajak dalam membayar PBB.

Pengaruh Tingkat Kepercayaan Pada Pemerintah dan Hukum Terhadap 
Kepatuhan Wajib Pajak Dalam Membayar PBB

Kepercayaan adalah (1) sesuatu yang dipercayai: (2) harapan dan keyakinan (akan kejujuran, kebaikan, dan sebagainya) (Kamus Besar Bahasa Indonesia, 2015). Menurut Doney et al., (1998) dalam Handayani, Faturokhman, dan Pratiwi (2012), kepercayaan adalah sesuatu yang diharapkan dari kejujuran dan perilaku kooperif yang berdasarkan saling berbagi norma-norma dan nilai yang sama. Kepercayaaan pada pemerintah dan hukum merupakan wujud harapan wajib pajak kepada aparat dalam menjalankan sistem pemerintahan dan hukum agar sesuai dengan norma dan nilai yang berlaku. Berdasarkan teori tindakan beralasan, wajib pajak akan mempertimbangkan tindakan yang harus diambilnya sesuai pikiran yang rasional. Persepsi wajib pajak mengenai kepercayaannya pada pemerintah dan hukum merupakan alasan dari aksi yang dapat mempengaruhi wajib pajak dalam membuat keputusan mengenai kepatuhan wajib pajak dalam melaksanakan kewajiban perpajakannya.

Perumusan hipotesis ini mengacu pada penelitian Alm, Vazquez, and Torgler (2005) yang menyimpulkan bahwa tingkat kepercayaan pada pemerintah dan hukum berpengaruh terhadap perilaku wajib pajak untuk patuh pada kewajiban perpajakannya. Argumentasi yang dipakai adalah wajib pajak yang memiliki tingkat kepercayaan pada sistem pemerintah dan hukum akan percaya bahwa iuaran yang diberikannya kepada kas negara dipergunakan dengan baik untuk keperluan negara sehingga wajib pajak semakin percaya pada pemerintah dan hukum yang membuat wajib pajak melaksanakan kewajiban perpajakannya dan menyebakan meningkatnya kepatuhan wajib pajak dalam membayar PBB. Berdasarkan penjelasan diatas dapat diambil hipotesis sebagai berikut:

$\mathrm{H}_{3}$ : Tingkat kepercayaan pada pemerintah dan hukum berpengaruh terhadap kepatuhan wajib pajak dalam membayar PBB.

\section{Pengaruh Nasionalisme Terhadap Kepatuhan Wajib Pajak Dalam Membayar PBB}

Nasionalisme adalah (1) paham (ajaran) untuk mencintai bangsa dan negara sendiri; sifat kenasionalan: makin menjiwai bangsa Indonesia; (2) kesadaran keanggotaan dalam suatu bangsa yang secara potensial atau aktual bersama-sama mencapai, mempertahankan, dan mengabadikan identitas, integritas, kemakmuran, dan kekuatan bangsa itu; semangat kebangsaan (Kamus Besar Bahasa Indonesia, 2015). Nasionalisme adalah suatu paham, yang berpendapat bahwa kesetiaan tertinggi individu harus 
diserahkan kepada negara kebangsaan (Kohn, 1984). Berdasarkan teori atribusi, nasionalisme merupakan penyebab internal yang dapat mempengaruhi persepsi wajib pajak dalam membuat keputusan mengenai perilaku kepatuhan wajib pajak dalam melaksanakan kewajiban perpajakannya.

Perumusan hipotesis ini mengacu pada penelitian Alm, Vazquez, and Torgler (2005) dimana kebanggaan nasional berpengaruh terhadap perilaku wajib pajak untuk patuh pada kewajiban perpajakan. Argumentasi yang dipakai adalah wajib pajak yang memiliki rasa nasionalisme akan timbul rasa tanggungjawabnya untuk membangun dan memajukan bangsa dan negaranya sehingga wajib pajak akan melaksanakan kewajiban perpajakannya dan meningkatkan kepatuhan wajib pajak dalam membayar PBB. Berdasarkan penjelasan diatas dapat diambil hipotesis sebagai berikut:

$\mathrm{H}_{4}$ : Nasionalisme berpengaruh terhadap kepatuhan wajib pajak dalam membayar PBB.

\section{METODE PENELITIAN DAN TEKNIK} ANALISIS DATA

\section{Jenis Penelitian}

Jenis penelitian yang digunakan dalam penelitian ini adalah penelitian kuantitatif dengan metode survei. Desain survei adalah prosedur dalam penelitian kuantitatif dimana peneliti mengatur pemeriksaan sampel atau untuk seluruh populasi untuk menggambarkan sikap, pendapat, perilaku, atau karakteristik populasi (Creswell, 2012:376).

\section{Populasi dan Sampel}

Populasi dalam penelitian ini adalah para wajib pajak PBB yang berada di Kota Banjar. Populasi berjumlah 109.326 wajib pajak PBB yang tercatat pada Dinas Pendapatan Pengelolaan Keuangan dan Aset Daerah per November 2015. Metode pengambilan sampel yang digunakan adalah menggunakan convenience sampling yaitu pengambilan sampel secara nyaman dilakukan dengan memilih sampel bebas sekehendak peneliti (Jogiyanto, 2013).

\section{Definisi Operasional dan Pengukuran Variabel}

\section{Kepatuhan Wajib Pajak (Y)}

Kepatuhan wajib pajak adalah ketaatan atau sikap patuh wajib pajak dalam membayar pajak bumi dan bangunan dengan benar secara tepat waktu dan jumlah yang tepat. Untuk mengukur kepatuhan wajib pajak digunakan instrumen berdasarkan Keputusan Menteri Keuangan Nomor 235/KMK.03/2003 mengenai kategori wajib pajak yang dikatakan patuh, terdiri dari sembilan item pertanyaan menggunakan skala likert 1-5. 


\section{Pemahaman Wajib Pajak Mengenai Peraturan Perpajakan $\left(\mathbf{X}_{1}\right)$}

Pemahaman wajib pajak mengenai peraturan perpajakan yaitu sejauh mana tingkat pemahaman wajib pajak mengenai peraturan perpajakan yang ada sehingga wajib sadar akan kewajibannya membayar pajak. Untuk mengukur pemahaman wajib pajak digunakan instrumen daftar pertanyaan Fauziyah (2008) yang terdiri dari tiga belas item pertanyaan menggunakan skala likert 1-5.

\section{Sanksi Perpajakan $\left(\mathrm{X}_{2}\right)$}

Sanksi perpajakan merupakan persepsi wajib pajak mengenai sanksi yang diterima apabila melanggar peraturan perpajakan. Untuk mengukur sanksi perpajakan digunakan instrumen daftar pertanyaan Jatmiko (2006) yang terdiri dari tujuh item pertanyaan menggunakan skala likert 1-5.

\section{Tingkat Kepercayaan Pada Pemerintah} dan Hukum $\left(X_{3}\right)$

Kepercayaan pada pemerintah dan hukum adalah mengukur mengenai sesuatu yang diharapkan wajib pajak dari sistem pemerintah dan hukum yang berlaku berdasarkan norma dan nilai yang ada. Untuk mengukur tingkat kepercayaan pada pemerintah dan hukum digunakan instrumen daftar pertanyaan Handayani, Faturokhman, dan Pratiwi (2012) yang terdiri dari delapan item pertanyaan menggunakan skala likert 1-5.

\section{Nasionalisme $\left(\mathbf{X}_{4}\right)$}

Nasionalisme adalah persepsi wajib pajak mengenai rasa cintanya pada tanah air. Untuk mengukur tingkat kepercayaan pada pemerintah dan hukum digunakan instrumen daftar pertanyaan Alm, Vazquez, and Torgler (2005) yang terdiri dari tujuh item pertanyaan menggunakan skala likert $1-5$.

\section{Skala Pengukuran}

Untuk mengukur instrumen dalam variabel penelitian ini, digunakan skala Likert dengan rentang 1 sampai dengan 5. Kriteria yang digunakan antara lain sebagai berikut:

a. Jawaban sangat setuju mendapat skor 5

b. Jawaban setuju mendapat skor 4

c. Jawaban ragu-ragu/netral mendapat skor 3

d. Jawaban tidak setuju mendapat skor 2 e. Jawaban sangat tidak setuju mendapat skor 1

\section{Analisis Regresi Berganda}

Analisis regresi berganda digunakan untuk mengetahui ada tidaknya pengaruh variabel independen terhadap variabel dependen. Untuk menguji hipotesis 1 sampai 4 digunakan analisis regresi 
berganda dengan model persamaan sebagai berikut:

$\mathrm{Y}=\alpha+\beta_{1} \mathrm{X}_{1}+\beta_{2} \mathrm{X}_{2}+\beta_{3} \mathrm{X}_{3}+\beta_{4} \mathrm{X}_{4}+\mathrm{e}$

Keterangan:

$\begin{array}{lll}\mathrm{Y} & = & \begin{array}{l}\text { Kepatuhan Wajib Pajak } \\ \text { Dalam Membayar PBB }\end{array} \\ \mathrm{X}_{1} & =\begin{array}{l}\text { Pemahaman Wajib } \\ \text { Pajak Mengenai } \\ \text { Peraturan Perpajakan }\end{array} \\ & = & \text { Sanksi Perpajakan } \\ \mathrm{X}_{2} & =\begin{array}{l}\text { Tingkat Kepercayaan } \\ \mathrm{X}_{3}\end{array} & \text { Pada Pemerintah dan } \\ & \text { Hukum } \\ \mathrm{X}_{4} & \text { Nasionalisme } \\ \beta_{1}, \beta_{2}, \beta_{3}, \beta_{4}= & \text { Koefisien Regresi } \\ \alpha & = & \text { Konstanta } \\ \mathrm{e} & = & \text { Variabel Gangguan }\end{array}$

\section{HASIL DAN PEMBAHASAN}

\section{Gambaran Umum Responden}

Penelitian ini meneliti tentang pengaruh pemahaman mengenai peraturan perpajakan, sanksi perpajakan, tingkat kepercayaan pada pemerintah dan hukum serta nasionalisme terhadap kepatuhan wajib pajak dalam membayar PBB. Responden dalam penelitian ini adalah para wajib pajak yang membayar pajak bumi dan bangunan perdesaan dan perkotaan. Populasi berjumlah 109.326 wajib pajak PBB yang terdiri dari 4 (empat) kecamatan, yaitu 31.071 wajib pajak di Kecamatan Banjar, 11.758 wajib pajak di Kecamatan Purwaharja, 35.198 di Kecamatan Pataruman, dan 31.299 di Kecamatan Langensari.

Metode pengambilan sampel yang digunakan adalah menggunakan convenience sampling yaitu pengambilan sampel secara nyaman dilakukan dengan memilih sampel bebas sekehendak peneliti (Jogiyanto, 2013:98). Jumlah responden dalam penelitian berjumlah 100 responden. Kuesioner yang dapat diolah adalah sebanyak 100 responden dengan respon rate sebesar $100 \%$. Sedangkan untuk deskripsi responden dapat dilihat pada lampiran 1.

\section{Uji Kualitas Data}

\section{Uji Validitas dan Uji Reliabilitas}

Uji validitas dilakukan untuk menguji keakuratan instrumen kuesioner. Item pertanyaan untuk masing-masing variabel menunjukkan bahwa nilai $\mathrm{r}_{\text {hitung }}$ korelasi product moment $>r_{\text {tabel }}(0,374)$ dengan tingkat kepercayaan 95\% maka untuk variabel pemahaman wajib pajak mengenai peraturan perpajakan terdapat tiga pertanyaan yang tidak valid, sedangkan untuk variabel sanksi perpajakan terdapat satu pertanyaan yang tidak valid. Setelah pertanyaan didrop dan dilakukan pengujian ulang maka semua item pertanyaan dalam kuesioner dinyatakan valid. Uji reliabilitas 
digunakan untuk menguji konsistensi data yang dikumpulkan. Pengujian reliabilitas kuesioner menggunakan rumus cronbach's alpha. Dari hasil perhitungan dalam penelitian ini setiap variabel memberikan nilai cronbach's alpha> 0,60. Maka dapat dikatakan reliable (Ghozali, 2006).

\section{Uji Asumsi Klasik}

\section{Uji Normalitas}

Berdasarkan hasil analisis dengan Kolmogorov-Smirnov dengan menggunakan bantuan SPSS 21.0 for windows pada lampiran 2 dengan kriteria pengujian nilai asympotic significant (two tailed $)>$ alpha $(\alpha=0,05)$, maka nilai residual memenuhi asumsi klasik atau berdistribusi normal. Diperoleh nilai Assymp. Sig sebesar 0,083 atau lebih besar dari alphanya $(\alpha=0,05)$, sehingga distribusi data pada variabel penelitian adalah normal, dan bisa dilanjutkan ke analisis selanjutnya.

\section{Uji Multikolinearitas}

Berdasarkan hasil output SPSS 21.0 for Windows pada lampiran 3 diketahui bahwa nilai tolerance value $\geq 0,1$ dan nilai $V I F<10$ yang berarti tidak terjadi gejala multikolinearitas.

\section{Uji Heteroskedastisitas}

Berdasarkan tabel hasil uji
heteroskedastisitas menggunakan SPSS
21.0 for Windows yang ada pada lampiran

4, diperoleh nilai signifikansi untuk semua variabel pada masing-masing persamaan > 0,05, sehingga dapat disimpulkan bahwa tidak terjadi heteroskedastisitas.

\section{Uji Lineritas}

Berdasarkan tabel hasil uji linearitas menggunakan SPSS 21.0 for Windows yang ada pada lampiran 5, diperoleh besarnya nilai Z1 adalah 0,579. Karena nilai Z1 lebih dari $0,05(0,579>0,05)$ maka hal ini menunjukkan bahwa model dikatakan linear.

\section{Pengujian Hipotesis}

Berdasarkan perhitungan regresi linear berganda (lampiran 6) diperoleh nilai koefisien determinasi $\mathrm{R}^{2}$ sebesar 0,473 menunjukkan bahwa keempat variabel independen (pemahaman mengenai peraturan perpajakan, sanksi perpajakan, tingkat kepercayaan pada pemerintah dan hukum, serta nasionalisme) mempengaruhi kepatuhan wajib pajak dalam membayar PBB sebesar 47.3\%. Dan sisanya sebesar $52.7 \%$ (diperoleh dari 100\% - 47.3\%) dipengaruhi oleh faktor-faktor lain yang tidak diteliti. Adapun persamaan yang diperoleh adalah sebagai berikut:

$$
\begin{aligned}
& Y=12,241+0,230 X_{1}+0,313 X_{2}+0,057 \\
& X_{3}+0,296 X_{4}+e
\end{aligned}
$$

Nilai konstanta bernilai 12,241 artinya kepatuhan wajib pajak dalam membayar PBB akan bernilai 12,241 
apabila pemahaman wajib pajak mengenai peraturan perpajakan, sanksi perpajakan, tingkat kepercayaan pada pemerintah dan hukum, serta nasionalisme bernilai nol atau konstan. Selain itu, responden dalam penelitian ini menunjukkan adanya kepatuhan wajib pajak dalam membayar PBB, hal tersebut dapat diketahui dengan nilai konstanta yang tidak bernilai nol atau negatif.

Nilai koefisien regresi untuk variabel pemahaman wajib pajak mengenai peraturan perpajakan sebesar 0,230 menyatakan apabila terjadi peningkatan pemahaman wajib pada mengenai peraturan perpajakan sebesar satu satuan sedangkan variabel lain tetap, maka akan meningkatkan kepatuhan wajib pajak dalam membayar PBB sebesar 0,230.

Nilai koefisien regresi variabel sanksi perpajakan sebesar 0,313 menyatakan apabila terjadi peningkatan penerapan sanksi perpajakan sebesar satu satuan sedangkan variabel lain tetap, maka akan meningkatkan kepatuhan wajib pajak dalam membayar PBB sebesar 0,313.

Nilai koefisien regresi variabel tingkat kepercayaan terhadap pemerintah dan hukum sebesar 0,057 menyatakan apabila terjadi peningkatan kepercayaaan pada pemerintah dan hukum sebesar satu satuan sedangkan variabel lain tetap, maka akan meningkatkan kepatuhan wajib pajak dalam membayar PBB sebesar 0,057.
Nilai koefisien regresi variabel nasionalisme sebesar 0,296 menyatakan apabila terjadi peningkatan nasionalisme sebesar satu satuan sedangkan variabel lain tetap, maka akan meningkatkan kepatuhan wajib pajak dalam membayar PBB sebesar 0,296

Berdasarkan hasil perhitungan regresi pada lampiran 7 maka, hasil uji Goodness of Fit dengan tingkat signifikasi $(\alpha)=0,05$ diperoleh nilai $F_{\text {hitung }}$ sebesar 23,185 > nilai $F_{\text {tabel }}$ sebesar 2,473 atau signifikasi sebesar $0,000>\alpha(0,05)$. Dapat disimpulkan adalah apabila $F_{\text {hitung }}>F_{\text {tabel }}$ atau Sig. $\leq \alpha(0,05)$, maka dapat dinyatakan bahwa keseluruhan variabel pemahaman wajib pajak mengenai peraturan perpajakan, sanksi perpajakan, tingkat kepercayaan pada pemerintah dan hukum, serta nasionalisme memiliki pengaruh terhadap variabel kepatuhan wajib pajak dalam membayar $\mathrm{PBB}$, atau dapat pula dinyatakan bahwa model regresi yang terbentuk dinyatakan cocok atau fit.

Berdasarkan tingkat keyakinan 95 persen $\left(\frac{\alpha}{2}=0,025\right)$ dan degree of freedom (n - k) dimana $\mathrm{n}=100$ dan $\mathrm{k}=5$. Diperoleh nilai $t_{\text {hitung }}$ sebesar $3,094>$ nilai $t_{\text {tabel }} 1,987$ atau nilai signifikansi $0,003<\frac{\alpha}{2}(0,025)$. Kesimpulannya adalah apabila nilai $t_{\text {hitung }}>$ $\mathrm{t}_{\text {tabel }}$ atau Sig. $\leq \frac{\alpha}{2}(0,025)$, maka hipotesis pertama didukung dalam penelitian ini. Dengan demikian variabel pemahaman wajib pajak mengenai peraturan perpajakan 
berpengaruh positif signifikan terhadap kepatuhan wajib pajak dalam membayar PBB di Kota Banjar sehingga hipotesis pertama $\left(\mathrm{H}_{1}\right)$ diterima. Hal ini dikarenakan wajib pajak PBB di Kota Banjar rata-rata memiliki pemahaman mengenai peraturan perpajakan yang baik sehingga dapat dikatakan tingkat kepatuhan wajib pajak menjadi tinggi. Umumnya wajib pajak telah mengetahui dan memahami undang-undang mengenai PBB, menghitung pajak sesuai peraturan, mengetahui hal-hal yang menyangkut SPPT, PBB untuk pembangunan daerah, dasar pengenaan PBB, pengajuan keberatan dan pengurangan serta cara pembayaran yang mudah dilakukan. Wajib pajak diharapkan semakin meningkatkan pemahaman tentang peraturan perpajakan yang berlaku sehingga dapat meningkatkan pembangunan daerah melalui perpajakan. Hasil penelitian ini sejalan dengan hasil penelitian yang dilakukan oleh Rahmawati, Prasetyo dan Rinawati (2013), Adiasa (2013) serta Imelda (2014) yang menyimpulkan bahwa pemahaman wajib pajak mengenai peraturan perpajakan berpengaruh terhadap kepatuhan wajib pajak.

Berdasarkan tingkat keyakinan 95 persen $\left(\frac{\alpha}{2}=0,025\right)$ dan degree of freedom $(\mathrm{n}-\mathrm{k})$ dimana $\mathrm{n}=100$ dan $\mathrm{k}=5$. Diperoleh nilai $t_{\text {hitung }}$ sebesar 2,256> nilai $\mathrm{t}_{\text {tabel }} 1,987$ atau nilai signifikansi $0,026 \geq$ $\frac{\alpha}{2}(0,025)$. Kesimpulannya adalah apabila nilai $t_{\text {hitung }}>t_{\text {tabel }}$ atau $\operatorname{Sig} \geq \frac{\alpha}{2}(0,025)$, maka hipotesis kedua didukung dalam penelitian ini. Dengan demikian variabel sanksi perpajakan berpengaruh positif signifikan terhadap kepatuhan wajib pajak dalam membayar PBB di Kota Banjar sehingga hipotesis kedua $\left(\mathrm{H}_{2}\right)$ diterima. Hal ini dikarenakan sanksi perpajakan bagi wajib pajak PBB di Kota Banjar telah dilaksanakan dengan baik sehingga dapat meningkatkan kepatuhan wajib pajak dalam membayar PBB. Umumnya wajib pajak merasa tarif denda yang dikenakan dianggap wajar, pelaksanaan sanksi denda bagi wajib pajak yang lalai telah dilaksanakan dengan tertib pada waktunya, wajib pajak merasa bahwa pembayaran setelah jatuh tempo akan dikenakan denda, dan wajib pajak merasa wajar ketika terjadi pelanggaran yang merugikan negara secara material harus dikenai sanksi pidana. Hasil penelitian ini sejalan dengan hasil penelitian Jatmiko (2006), Muliari dan Setiawan (2010), Rustiyaningsih (2011), Kumiati dan Favriera (2011), Permatasari dan Yaniartha (2012), Jotopurnomo dan Mangoting (2013),serta Wulandari dan Suyanto (2014) yang menyatakan sanksi perpajakan berpengaruh terhadap kepatuhan wajib pajak. 
Berdasarkan tingkat keyakinan 95 persen $\left(\frac{\alpha}{2}=0,025\right)$ dan degree of freedom $(\mathrm{n}$ - k) dimana $\mathrm{n}=100$ dan $\mathrm{k}=5$. Diperoleh nilai $t_{\text {hitung }}$ sebesar $0,621<$ nilai $t_{\text {tabel }} 1,987$ atau nilai signifikansi $0,536>\frac{\alpha}{2}(0,025)$. Kesimpulannya adalah apabila nilai $t_{\text {hitung }}<$ $t_{\text {tabel }}$ atau Sig. $>\frac{\alpha}{2}(0,025)$, maka hipotesis ketiga tidak didukung dalam penelitian ini. Dengan demikian variabel adalah tingkat kepercayaan pada pemerintah dan hukum tidak berpengaruh terhadap kepatuhan wajib pajak dalam membayar PBB di Kota Banjar sehingga hipotesis ketiga $\left(\mathrm{H}_{3}\right)$ ditolak. Hal ini dikarenakan adanya wajib pajak yang belum percaya penuh terhadap aparat pemerintah maupun sistem hukum yang berjalan dikarenakan wajib pajak merasa adanya pengeluaran yang digunakan tidak sesuai dengan fungsi dan tugas pemerintah, kurangnya pemenuhan kesejahteraan bagi rakyat, masih ada perbedaan perlakuan dalam sistem hukum sehingga dirasa adanya ketidakadilan. Kemudian pernah adanya kasus penggelapan pajak yang dilakukan oleh fiskus, serta terjadinya tindakan korupsi yang dilakukan pejabat ataupun wakil rakyat. Hasil ini sejalan dengan penelitian yang dilakukan Handayani, Faturokhman, dan Pratiwi (2012) yang menyimpulkan bahwa tingkat kepercayaan pada pemerintah dan hukum tidak berpengaruh terhadap kemauan membayar pajak sehingga tidak berpengaruh pula terhadap kepatuhan wajib pajak.

Berdasarkan tingkat keyakinan 95 persen $\left(\frac{\alpha}{2}=0,025\right)$ dan degree of freedom (n - k) dimana $\mathrm{n}=100$ dan $\mathrm{k}=5$. Diperoleh nilai $t_{\text {hitung }}$ sebesar 3,072> nilai $t_{\text {tabel }} 1,987$ atau nilai signifikansi $0,003<\frac{\alpha}{2}(0,025)$. Kesimpulannya adalah apabila nilai $t_{\text {hitung }}>$ $\mathrm{t}_{\text {tabel }}$ atau Sig. $\leq \frac{\alpha}{2}(0,025)$, maka hipotesis keempat didukung dalam penelitian ini. Dengan demikian variabel adalah nasionalisme berpengaruh positif signifikan terhadap kepatuhan wajib pajak dalam membayar PBB di Kota Banjar sehingga hipotesis keempat $\left(\mathrm{H}_{4}\right)$ diterima. Hal ini dikarenakan wajib pajak PBB di Kota Banjar rata-rata memiliki rasa nasionalisme yang tinggi sehingga dapat dikatakan tingkat kepatuhan wajib pajak menjadi tinggi. Wajib pajak memiliki rasa kebanggaan menjadi bagian warga negara Indonesia, merasa bertanggungjawab dalam melaksanakan kewajiban membayar PBB, merasa turut berperan dalam pembangunan. Wajib pajak menyadari bahwa ketaatan membayar pajak merupakan tindakan sebagai warga negara yang baik serta wujud cinta pada tanah air. Kemudian wajib pajak menyadari dengan membayar PBB membantu wujudkan tujuan negara. Oleh sebab itu, wajib pajak diharapkan tetap memiliki rasa nasionalisme yang tinggi sehingga dapat meningkatkan 
pendapatan asli daerah yang dapat membantu terhadap pemenuhan kesejahteraan masyarakat melalui pembayaran PBB. Hasil ini sejalan dengan penelitian yang dilakukan oleh Alm, Vazquez, and Torgler (2005) menyimpulkan bahwa nasionalisme berpengaruh terhadap perilaku wajib pajak dalam kepatuhan membayar pajak.

\section{KESIMPULAN DAN IMPLIKASI}

Berdasarkan hasil penelitian maka dapat disimpulkan: (1) Pemahaman wajib pajak mengenai peraturan perpajakan berpengaruh posistif signifikan terhadap kepatuhan wajib pajak dalam membayar PBB. (2) Sanksi perpajakan berpengaruh positif signifikan terhadap kepatuhan wajib pajak dalam membayar PBB. (3) Tingkat kepercayaan pemerintah dan hukum tidak berpengaruh terhadap kepatuhan wajib pajak dalam membayar PBB.

Nasionalisme berpengaruh positif signifikan terhadap kepatuhan wajib pajak dalam membayar PBB.

Berdasarkan kesimpulan diatas dapat ditarik garis besarnya bahwa tingkat kepercayaan pada pemerintah dan hukum menunjukkan hasil yang tidak mempengaruhi kepatuhan wajib pajak dalam membayar PBB, sehingga perlu melakukan perbaikan sikap aparat pemerintah dengan menegakkan kedisplinan dan budaya berperilaku jujur dan perbaikan sistem hukum yang ada dengan pemberantasan ketidakadilan sehingga mendorong kepercayaan wajib pajak terhadap pemerintah dan hukum.

Penelitian ini hanya dilakukan di Kota Banjar, penelitian selanjutnya diharapkan dapat memperluas lingkup penelitian agar dapat memberikan kontribusi yang lebih berarti, seperti melakukan perbandingan diantara dua kota/kabupaten yang berbeda. Peneliti yang tertarik untuk melakukan kajian di bidang yang sama dapat menggunakan variabelvariabel yang tidak digunakan dalam penelitian ini, hal ini dapat dilakukan karena nilai koefisien determinasi dalam penelitian ini masih dapat ditingkatkan dengan adanya penambahan variabel independen seperti kesadaran wajib pajak, tingkat pendapatan, faktor demografi, dan kualitas pelayanan fiskus.

\section{DAFTAR PUSTAKA}

Adiasa, Nirawan. 2013. Pengaruh Pemahaman Peraturan Pajak Terhadap Kepatuhan Wajib Pajak Dengan Moderating Preferensi Risiko. Accounting Analysis Journal. Vol. 2. No. 3.

Creswell, John W. 2012. Educational Research; Planning, Conducting and Evaluating Quantitative and Qualitative Research. Pearson. United States of America.

Direktorat Jenderal Pajak. 2015. Realisasi Penerimaan Pajak per 31 Agustus 2015. 
http://www.pajak.go.id/content/realis asi-penerimaan-pajak-31-agustus-

$\underline{2015}$ diakses pada tanggal 2 November 2015.

Fauziyah, Laily. 2008. Pengaruh Karakteristik PadaWajib Pajak TerhadapKeberhasilan

PenerimaanPBB di Kantor Pelayanan PBB JakartaSelatanSatu. Skripsi Jakarta: UIN SyarifHidayatullah.

Ghozali, I. 2006. Aplikasi Analisis Multivariate dengan program SPSS. Badan Penerbit Universitas Diponegoro. Semarang.

Handayani, Sapti Wuri., Agus Faturokhman., dan Umi Pratiwi. 2012. Faktor-Faktor Yang Mempengaruhi Kemauan Membayar Pajak Wajib Pajak Orang Pribadi Yang Melakukan Pekerjaan Bebas. Simposium Nasional Akuntansi XV Banjarmasin.

Hartono, Jogiyanto. 2007. Sistem Informasi Keperilakuan. Penerbit ANDI. Yogyakarta.

Imelda, Bona. 2014. Analisis Faktor-Faktor Yang Mempengaruhi Kepatuhan wajib Pajak Orang Pribadi (Studi Pada Kantor Pelayanan Pajak Pratama Semarang). Skripsi Program Sarjana Jurusan Akuntansi Fakultas Ekonomika dan Bisnis Universitas Diponegoro Semarang.

2013. Metodelogi Penelitian Bisnis; Salah Kaprah dan PengalamanPengalaman. BPFE-Yogyakarta. Yogyakarta.

Jatmiko, Agus. 2006. Pengaruh Sikap Wajib Pajak pada Pelaksanaan Sanksi Denda,Pelayanan Fiskus, dan Kesadaran Perpajakan Terhadap Kepatuhan Wajib PajakStudi Empiris Terhadap Wajib Pajak Orang Pribadi di Kota Semarang.Universitas
Diponegoro: Tesis Megister Akuntansi

Jotopurnomo, Cindy., dan Yenni Mangoting. 2013. Pengaruh Kesadaran Wajib Pajak, Kualitas Pelayanan Fiskus, Sanksi Perpajakan, Lingkungan Wajib Pajak Berada terhadap Kepatuhan Wajib Pajak Orang Pribadi di Surabaya. Tax \& Accounting Review. Vol.1 No.1.

Kamus Besar Bahasa Indonesia. 2015. http://kbbi.web.id/patuh, diakses pada tanggal 06 Desember 2015.

2015. http://kbbi.web.id/paham, diakses pada tanggal 06 Desember 2015.

2015. http://kbbi.web.id/sanksi, diakses pada tanggal 06 Desember 2015.

2015. http://kbbi.web.id/percaya, diakses pada tanggal 06 Desember 2015.

2015.

http://kbbi.web.id/nasionalisme, diakses pada tanggal 06 Desember 2015.

Kementerian Keuangan. 2015. Realisasi Pendapatan Negara Tahun 2014 Capai Rp1.537,2 Triliun.http://www.kemenkeu.go.id/B erita/realisasi-pendapatan-negaratahun-2014-capai-rp15372-triliun diakses pada tanggal 22 November 2015.

Kurniati, Amalia., dan Sotya Fevriera. 2011. Analisis Pengaruh Sosialisasi, Sanksi dan Faktor-Faktor Demografi Terhadap Kepatuhan Wajib Pajak PBB di Surakarta. Jurnal Bisnis dan Ekonomi. Vol. 15. No.2.

Kohn, Hans.1984. Nasionalisme: Arti dan Sejarahnya. Erlangga. Jakarta. 
Mardiasmo. 2011. Perpajakan Edisi Revisi. Penerbit ANDI. Jakarta.

Muliari, Ni Ketut., dan Putu Ery Setiawan. 2010. Pengaruh Persepsi Tentang Sanksi Perpajakan Dan Kesadaran Wajib Pajak Pada Kepatuhan Pelaporan Wajib Pajak Orang Pribadi Di Kantor Pelayanan Pajak Pratama Denpasar Timur. Jurnal Universitas Udayana Bali.

Nurhandoko Wiyoso. 2015. PBB Kota Banjar Baru Lunas 19 Persen.http://www.pikiranrakyat.com/jawabarat/2015/04/09/322857/pbb-kotabanjar-baru-lunas-19-persen diakses pada tanggal 05 Desember 2015.

Pemerintahan Republik Indonesia. UndangUndang Republik Indonesia Nomor 28 Tahun 2007 Tentang Perubahan Ketiga Atas Undang-Undang Nomor 6 Tahun 1983 Tentang Ketentuan Umum Dan Tata Cara Perpajakan.

Undang-Undang No 28 Tahun 2009 Tentang Pajak Daerah dan Retribusi Daerah.

Permatasari, Aprilia., dan P. D'yan Yaniartha. 2012. Pengaruh Kesadaran
WP Dan Sanksi Perpajakan Pada Kepatuhan WP Dalam Membayar PBB. Jurnal Univeristas Udayana Bali.

Rahmawati, Lusi., Prasetyo dan Yuni Rinawati. 2013. Pengaruh Sosialisasi dan Pengetahuan Perpajakan Terhadap Tingkat Kesadaran dan Kepatuhan Wajib Pajak. Prosiding Simposium Nasional Perpajakan 4.

Robbins, Stephen P. 2001. Perilaku Organisasi : Konsep, Kontroversi dan Aplikasi. Versi Bahasa Indonesia. Prenhallindo. Jakarta.

Rustiyaningsih, Sri. 2011. Faktor-Faktor Yang Menpengaruhi Kepatuhan Wajib Pajak. Jurnal Widya Warta. No. 02. Tahun XXXV.

Wulandari, Tika dan Suyanto. 2014. Pengaruh Pengetahuan Perpajakan, Tingkat Pendidikan, dan Sanksi Administrasi Terhadap Kepatuhan Wajib Pajak Dalam Melakukan Pembayaran Pajak Bumi dan Bangunan. Jurnal Akuntansi. Vol. 2. No. 2. 


\section{Lampiran 1. Deskripsi Responden}

\begin{tabular}{|c|c|c|c|c|}
\hline No & Informasi & Keterangan & Jumlah & $\%$ \\
\hline \multirow[t]{5}{*}{1} & \multirow[t]{5}{*}{ Usia } & $\leq 20$ tahun & 2 & 2 \\
\hline & & 21-30 tahun & 25 & 25 \\
\hline & & 31-40 tahun & 39 & 39 \\
\hline & & 41-50 tahun & 29 & 29 \\
\hline & & $\geq 50$ tahun & 15 & 15 \\
\hline \multicolumn{2}{|r|}{ Jumlah } & & 100 & 100 \\
\hline \multirow[t]{3}{*}{2} & Jenis Kelamin & Pria & 60 & 60 \\
\hline & & Wanita & 40 & 40 \\
\hline & Jumlah & & 100 & 100 \\
\hline \multirow[t]{8}{*}{3} & \multirow{8}{*}{$\begin{array}{c}\text { Tingkat } \\
\text { Pendidikan }\end{array}$} & D1 & 1 & 1 \\
\hline & & D2 & 2 & 2 \\
\hline & & D3 & 7 & 7 \\
\hline & & $\mathrm{S} 1$ & 34 & 34 \\
\hline & & $\mathrm{S} 2$ & 6 & 6 \\
\hline & & Lainnya & 50 & 50 \\
\hline & & (SMA & & \\
\hline & & Sederajat) & & \\
\hline & Jumlah & & 100 & 100 \\
\hline
\end{tabular}

\section{Lampiran 2. Hasil Uji Normalitas}

One-Sample Kolmogorov-Smirnov Test

\begin{tabular}{|c|c|c|c|}
\hline & & $\begin{array}{l}\text { Unstandardiz } \\
\text { ed Residual }\end{array}$ & $\begin{array}{l}\text { Standardized } \\
\text { Residual }\end{array}$ \\
\hline \multicolumn{2}{|l|}{$\mathrm{N}$} & 100 & 100 \\
\hline \multirow[b]{2}{*}{ Normal Parameters ${ }^{\mathrm{a}, \mathrm{b}}$} & Mean & ,0000000 & ,0000000 \\
\hline & $\begin{array}{l}\text { Std. } \\
\text { Deviation }\end{array}$ & 2,82647032 & ,97958969 \\
\hline \multirow{3}{*}{$\begin{array}{l}\text { Most Extreme } \\
\text { Differences }\end{array}$} & Absolute &, 126 &, 126 \\
\hline & Positive & ,126 &, 126 \\
\hline & Negative &,- 064 &,- 064 \\
\hline \multicolumn{2}{|l|}{ Kolmogorov-Smirnov Z } & 1,262 & 1,262 \\
\hline \multicolumn{2}{|l|}{ Asymp. Sig. (2-tailed) } & 083 & 083 \\
\hline
\end{tabular}

a. Test distribution is Normal.

b. Calculated from data. 


\section{Lampiran 3. Hasil Uji Multikolinearitas}

\section{Coefficients $^{\mathrm{a}}$}

\begin{tabular}{|c|c|c|c|c|c|c|}
\hline \multirow{2}{*}{\multicolumn{2}{|c|}{ Model }} & \multicolumn{3}{|c|}{ Correlations } & \multicolumn{2}{|c|}{$\begin{array}{c}\text { Collinearity } \\
\text { Statistics }\end{array}$} \\
\hline & & $\begin{array}{l}\text { Zero- } \\
\text { order }\end{array}$ & Partial & Part & Tolerance & VIF \\
\hline \multirow{4}{*}{1} & Pemahaman & ,636 & ,303 & ,226 & ,455 & 2,195 \\
\hline & Sanksi & ,516 & ,226 & , 165 &, 573 & 1,746 \\
\hline & Kepercayaan & ,493 & ,064 & 045 & ,514 & 1,945 \\
\hline & Nasionalisme & ,521 & ,301 & ,224 & ,720 & 1,389 \\
\hline
\end{tabular}

a. Dependent Variable: Kepatuhan

\section{Lampiran 4. Hasil Uji Heteroskedastisitas}

\section{Coefficients $^{\mathrm{a}}$}

\begin{tabular}{|c|c|c|c|c|c|c|}
\hline \multirow{2}{*}{\multicolumn{2}{|c|}{ Model }} & \multicolumn{2}{|c|}{$\begin{array}{l}\text { Unstandardized } \\
\text { Coefficients }\end{array}$} & \multirow{2}{*}{$\begin{array}{c}\begin{array}{c}\text { Standardized } \\
\text { Coefficients }\end{array} \\
\text { Beta }\end{array}$} & \multirow[t]{2}{*}{$\mathrm{t}$} & \multirow[t]{2}{*}{ Sig. } \\
\hline & & $\mathrm{B}$ & Std. Error & & & \\
\hline \multirow{5}{*}{1} & (Constant) & ,961 & ,627 & & 1,532 & , 129 \\
\hline & Pemahaman &,- 007 & ,015 &,- 069 &,- 465 & ,643 \\
\hline & Sanksi &,- 023 & 029 &,- 105 &,- 787 & ,433 \\
\hline & Kepercayaan &,- 008 & ,019 &,- 059 &,- 418 & ,677 \\
\hline & Nasionalisme &, 025 &, 020 & , 151 & 1,270 & ,207 \\
\hline
\end{tabular}

a. Dependent Variable: abres

\section{Lampiran 5. Hasil Uji Linearitas}

\section{Coefficients $^{\mathrm{a}}$}

\begin{tabular}{|c|c|c|c|c|c|c|}
\hline \multirow{2}{*}{\multicolumn{2}{|c|}{ Model }} & \multicolumn{2}{|c|}{$\begin{array}{l}\text { Unstandardized } \\
\text { Coefficients }\end{array}$} & \multirow{2}{*}{$\begin{array}{c}\text { Standardized } \\
\text { Coefficients }\end{array}$} & \multirow[t]{2}{*}{$\mathrm{t}$} & \multirow[t]{2}{*}{ Sig. } \\
\hline & & $\mathrm{B}$ & Std. Error & & & \\
\hline \multirow{6}{*}{1} & (Constant) & 18,802 & 9,892 & & 1,901 & ,065 \\
\hline & Pemahaman & ,272 & ,154 & ,302 & 1,768 & ,085 \\
\hline & Sanksi & ,286 & 235 & ,248 & 1,219 & 230 \\
\hline & Kepercayaan &,- 007 & , 149 &,- 009 &,- 044 & ,965 \\
\hline & Nasionalisme &, 160 & ,227 &, 104 & ,706 & ,484 \\
\hline & $\mathrm{Z} 1$ & ,494 & ,883 & ,091 & ,560 & ,579 \\
\hline
\end{tabular}

a. Dependent Variable: Kepatuhan 


\section{Lampiran 6. Hasil Regresi Berganda}

\begin{tabular}{|c|c|c|c|}
\hline \multicolumn{4}{|c|}{ Variables Entered/Removed ${ }^{a}$} \\
\hline Model & $\begin{array}{l}\text { Variables } \\
\text { Entered }\end{array}$ & $\begin{array}{l}\text { Variables } \\
\text { Removed }\end{array}$ & Method \\
\hline 1 & $\begin{array}{l}\text { Nasionalisme } \\
\text {, Sanksi, } \\
\text { Kepercayaan, } \\
\text { Pemahaman }^{\text {bemana }}\end{array}$ & & Enter \\
\hline
\end{tabular}

a. Dependent Variable: Kepatuhan

b. All requested variables entered.

\section{Model Summary}

\begin{tabular}{lrrrr}
\hline Model & R & R Square & $\begin{array}{c}\text { Adjusted R } \\
\text { Square }\end{array}$ & $\begin{array}{r}\text { Std. Error of } \\
\text { the Estimate }\end{array}$ \\
\hline 1 &, $703^{\mathrm{a}}$ &, 494 &, 473 & 2,88536 \\
\hline
\end{tabular}

a. Predictors: (Constant), Nasionalisme, Sanksi,

Kepercayaan, Pemahaman

\section{ANOVA $^{\mathrm{a}}$}

\begin{tabular}{rlrrrrr}
\hline Model & & \multicolumn{1}{c}{$\begin{array}{c}\text { Sum of } \\
\text { Squares }\end{array}$} & df & \multicolumn{1}{c}{$\begin{array}{c}\text { Mean } \\
\text { Square }\end{array}$} & F & Sig. \\
\hline \multirow{2}{*}{1} & Regression & 772,085 & 4 & 193,021 & 23,185 &, $000^{\mathbf{b}}$ \\
& Residual & 790,905 & 95 & 8,325 & & \\
& Total & 1562,990 & 99 & & & \\
\hline
\end{tabular}

a. Dependent Variable: Kepatuhan

b. Predictors: (Constant), Nasionalisme, Sanksi, Kepercayaan, Pemahaman

Coefficients $^{\mathrm{a}}$

\begin{tabular}{|c|c|c|c|c|c|}
\hline \multirow[t]{2}{*}{ Model } & \multicolumn{2}{|c|}{$\begin{array}{c}\text { Unstandardized } \\
\text { Coefficients }\end{array}$} & \multirow{2}{*}{$\begin{array}{c}\text { Standardized } \\
\text { Coefficients } \\
\text { Beta } \\
\end{array}$} & \multirow[t]{2}{*}{$\mathrm{t}$} & \multirow[t]{2}{*}{ Sig. } \\
\hline & $\mathrm{B}$ & Std. Error & & & \\
\hline (Constant) & 12,241 & 3,031 & & 4,038 &, 000 \\
\hline Pemahaman & ,230 & ,074 & ,335 & 3,094 & ,003 \\
\hline Sanksi & ,313 & , 139 & ,218 & 2,256 & ,026 \\
\hline Kepercayaan & ,057 & ,092 & ,063 & ,621 & ,536 \\
\hline Nasionalisme & ,296 & ,096 & ,264 & 3,072 & ,003 \\
\hline
\end{tabular}

a. Dependent Variable: Kepatuhan 